\title{
ANALISIS EKONOMI USAHATANI PADI ORGANIK DI PRIGEN PASURUAN
}

\author{
Wenny Mamilianti* \\ *Dosen Fakultas Pertanian Universitas Yudharta Pasuruan \\ Imail: mamiliantiw@yahoo.co.id
}

\begin{abstract}
ABSTRAK
Tujuan Penelitian (1) mengetahui dan mempelajari biaya, penerimaan, keuntungan dan kelayakan usahatani padi sawah organik dibandingkan usahatani padi konvensional di Kecamatan Pandaan, Kabupaten Pasuruan. (2) mengetahui faktor produksi yang mempengaruhi produksi padi organik dan konvensional di Kecamatan Pandaan, Kabupaten Pasuruan (3) mengetahui efisiensi faktor produksi dan tingkat skala usahatani (return to scale). Analisis data menggunakan Analisis Data menggunakan analisis Kelayakan Usahatani Pengaruh, Faktor Produksi Terhadap Produksi Padi, Efisiensi Faktor Produksi dan Tingkat Skala Usaha (Return to Scale). Hasil dari penelitian ini adalah Usahatani padi organik menguntungkan dan layak untuk dilakukan ditinjau dari nilai RCR organik 2,72 dan nilai RCR konvensional 2,42. Keuntungan usahatani padi sawah organik adalah $\mathrm{Rp} 3.521 .148 / \mathrm{ha}$ atau 36\% lebih tinggi dibandingkan konvensional sebesar Rp. 2.261.891/ha. Berdasarkan uji t, perbedaan keuntungan tersebut nyata pada taraf kepercayaan 95\%.Faktor produksi lahan, tenaga kerja, benih, pupuk urea, pupuk $\mathrm{KCl}$, pupuk SP36 dan pestisida secara simultan berpengaruh nyata terhadap produksi padi organik maupun konvensional. Untuk organik, variasi faktor produksi memberikan kontribusi 69,1\% terhadap variasi produksi padi organik, sedangkan untuk konvensional, variasi faktor produksi memberikan kontribusi $81,8 \%$ terhadap variasi produksi padi konvensional.Faktor produksi yang dominan mempengaruhi produksi padi sawah organik adalah luas lahan dan pupuk urea, sedangkan pada padi sawah konvensional adalah luas lahan, tenaga kerja dan benih.Faktor produksi lahan, tenaga kerja, benih, pupuk urea, pupuk $\mathrm{KCl}$, pupuk SP36 dan pestisida masih sangat kurang untuk produksi padi organik, sehingga perlu ditambahkan untuk mencapai tingkat yang efisien.Faktor produksi lahan, tenaga kerja, benih, pupuk urea, pupuk $\mathrm{KCl}$, dan pestisida masih sangat kurang untuk produksi padi konvensional sehingga perlu ditambahkan untuk mencapai tingkat yang efisien. Faktor produksi pupuk SP36 sudah berlebihan sehingga perlu dikurangi untuk mencapai tingkat yang efisien. Proses produksi padi organik maupun konvensional berada pada tingkat skala usaha yang meningkat (increasing return to scale) yang berarti apabila semua faktor produksi ditambah sebesar satu unit, maka produksi akan meningkat lebih besar dari satu unit.
\end{abstract}

Kata Kunci : analisis ekonomi, padi organik, prigen, pasuruan 


\section{PENDAHULUAN}

Upaya-upaya pemerintah yang telah dilaksanakan dalam pembangunan pertanian di Indonesia adalah dengan usaha-usaha intensifikasi, ekstensifikasi, diversifikasi dan rehabilitasi. Usaha intensifikasi yaitu usaha pemantapan sumber daya alam dengan menerapkan teknologi tepat guna dalam berbagai kondisi lahan yang ada. Usaha ekstensifikasi yaitu usaha luas areal panen dengan peningkatan optimasi areal yang dapat diusahakan untuk tanaman pangan. Usaha diversifikasi yaitu berupa penganekaragaman usaha tanaman pangan baik secara vertikal (pengembangan produksi setelah panen) maupun secara horizontal (pengembangan antara berbagai komoditas dan wilayah). Usaha rehabilitasi yaitu kegiatan-kegiatan pemulihan kemampuan berproduksi dari sumber daya alam yang ada. Usaha ini dilakukan dengan cara pemanfaatan lahan pekarangan, penghijauan atau reboisasi, dan optimasi lahan pasang surut. Di antara tanaman pangan di atas, padi merupakan bahan makanan yang sangat vital bagi kebutuhan manusia. Bahan makanan padi mengandung gizi dan penguat yang cukup bagi tubuh manusia, sebab di dalamnya terkandung bahan-bahan yang mudah diubah menjadi energi. Oleh sebab itu padi disebut juga makanan energi.

Dalam peningkatan produktivitas dan mendukung swasembada nasional, penetapan intensifikasi, ekstensifikasi, diversifikasi dan rehabilitasi di Provinsi Jawa Timur dilanjutkan dengan perencanaan dan penyelenggaraan yang terpadu dan disesuaikan dengan kondisi tanah, air, iklim, serta memelihara kelestarian dan kemampuan sumberdaya alam lingkungan hidup (Anonymous, 1997).

Di Kabupaten Pasuruan, Provinsi Jawa Timur padi merupakan komoditas tanaman pangan yang bisa diandalkan karena selain untuk memenuhi kebutuhan domestik, pangsa pasarnya lebih dikenal di Jawa Timur dibandingkan dengan pasar konvensional. Penghasil padi terbesar adalah Kecamatan Sukorejo, diikuti Kecamatan Pandaan (Tabel 1).

Secara umum pengelolaan usahatani padi di Kabupaten Pasuruan mengalami peningkatan walaupun sebenarnya tidak merata, dengan potensi luas lahan potensial mencapai 15.000 hektar dan baru digarap 57\% lahan sawah yang diupayakan sekitar 
$23 \%$ dengan total produksi $36.310,43$

ton. Berdasarkan jumlah penduduk Kabupaten Pasuruan sebesar 75,6 ribu jiwa, maka diperlukan 90.720.000 ton beras per tahun (Badan Pusat Statistik Kabupaten Pasuruan, 2015). peningkatan produktivitas padi sawah perlu terus dilakukan seiring dengan pertambahan penduduk.

Salah satu upaya yang telah dan sedang dilakukan oleh pemerintah untuk meningkatkan produksi padi dan sekaligus meningkatkan pendapatan petani di Desa Prigen, Kecamatan Pandaan, sebagai penghasil padi kedua terbesar di Kabupaten Pasuruan, adalah dengan memperkenalkan padi organik kepada petani. Organik tersebut di atas selain mempunyai produktivitas tinggi, juga mempunyai umur yang relatif pendek.

Meskipun telah cukup banyak informasi yang menunjukkan bahwa usahatani padi sawah layak dan menguntungkan untuk dilaksanakan, upaya pengembangan usahatani padi, terutama padi organik, di Desa Prigen, Kecamatan Pandaan, Kabupaten Pasuruan sampai saat ini masih belum membuahkan hasil yang memuaskan. Hal ini disebabkan oleh berbagai kendala yang antara lain meliputi kerterbatasan modal petani, lambannya adopsi teknologi budidaya padi sawah oleh petani, dan berbagai kendala sosial lainnya. Salah satu kendala penting yang menyebabkan banyak petani masih enggan menggunakan bibit organik adalah masih terbatasnya informasi tentang kelayakan usahatani dan faktor produksi yang mempengaruhi produksi padi. Sebagai akibatnya, petani lebih memilih menggunakan bibit konvensional karena dianggap mudah dan murah untuk dilakukan, walaupun hanya dengan produksi yang terbatas.

\subsection{Tujuan Penelitian}

Tujuan penelitian ini adaLah untuk:

1. Mengetahui dan mempelajari biaya, penerimaan, keuntungan dan kelayakan usahatani padi sawah organik dibandingkan usahatani padi konvensional di Kecamatan Pandaan, Kabupaten Pasuruan.

2. Mengetahui faktor produksi yang mempengaruhi produksi padi organik dan konvensional di Kecamatan Pandaan, Kabupaten Pasuruan, sebagai upaya untuk meningkatkan efisiensi penggunaan faktor produksi. 
3. Mengetahui efisiensi faktor produksi dan tingkat skala usahatani (return to scale)

\subsection{Manfaat Penelitian}

Hasil penelitian ini diharapkan dapat bermanfaat bagi pemerintah daerah sebagai bahan informasi untuk menentukan berbagai kebijakan dan operasional di lapangan sehingga adanya relevansi anjuran pemerintah dengan kondisi fisik, sosial dan ekonomi yang ada di Kabupaten Pasuruan khususnya petani padi konvensional dan padi organik di Desa Prigen, Kecamatan Pandaan, supaya dalam kegiatan usahataninya mampu meningkatkan produktivitas dan pendapatan petani.

\section{METODOLOGI PENELITIAN}

Penelitian ini dilakukan di Desa Prigen, Kecamatan Pandaan, Kebupaten Pasuruan, Provinsi Jawa Timur. Pemilihan lokasi penelitian dilakukan secara sengaja atas dasar pertimbangan bahwa di Desa tersebut sudah ada petani yang budidaya padi organik.

Populasi yang digunakan dalam penelitian ini adalah petani di Desa Prigen, Kecamatan Pandaan, Kebupaten Pasuruan, yang melaksanakan usahatani padi organik. Pengambilan petani sampel dilakukan secara acak bertingkat menurut metode Singarimbun (1989). Petani padi sawah sebanyak 224 petani dikelompokkan menjadi dua kelompok atas jenis budidaya yang diusahakan, yaitu organik (105 petani) dan non organik (119 petani). Dari masing-masing kelompok petani kemudian secara acak diambil 30 petani sampel sebagai responden, sehingga jumlah petani sampel seluruhnya adalah 60 orang petani.

\section{Analisis Data}

\section{a. Kelayakan Usahatani}

Kelayakan/efisiensi usahatani di ukur berdasarkan nilai RCR (revenue cost ratio), yaitu perbandingan antara penerimaan (revenue) dengan biaya (cost). Persamaan yang digunakan untuk memperoleh nilai RCR adalah sebagai berikut: Biaya Produksi TC = $\mathrm{TVC}+\mathrm{TFC}$ dimana:

$$
\begin{aligned}
\pi= & \text { Keuntungan usahatani padi }(\mathrm{Rp}) \\
\mathrm{Py}= & \text { Price per unit of yield } \\
& \text { (harga per satuan) produksi padi }
\end{aligned}
$$




$$
\begin{aligned}
& \left(\mathrm{Rp} / \mathrm{kg}^{-}\right) \\
& \mathrm{RCR}=\text { Revenue-cost ratio } \\
& \mathrm{TC}=\text { total costs (biaya total) } \\
& \text { usahatani padi }(\mathrm{Rp}) \\
& \mathrm{TR}=\text { total revenue }(\text { penerimaan total }) \\
& \mathrm{Y}=\text { total yield } \text { (produksi total) } \\
& \text { usahatani padi (kg/ha) }
\end{aligned}
$$

\section{b. Pengaruh Faktor Produksi}

\section{Terhadap Produksi Padi}

Pengaruh faktor produksi (luas lahan, tenaga kerja, benih, pupuk urea, pupuk SP36, pupuk $\mathrm{KCl}$, dan pestisida) terhadap produksi padi sawah, data yang terkumpul di analisis dengan menggunakan model fungsi produksi Cobb-Douglas. Model ini diasumsikan bahwa responden terhadap masukan (input) bersifat tetap terhadap keluaran (output). Persamaan umum dari model tersebut adalah sebagai berikut (Soekartawi et al., 1986):

$$
\ln Y=\ln \mathrm{bo}+\mathrm{bi} \sum_{\mathrm{i}=1}^{5} \ln \mathrm{Xi}+\mathrm{e}
$$

dimana:

$$
\begin{aligned}
\mathrm{Y} & =\text { Produksi } \\
\mathrm{bo} & =\text { Intercept } / \text { konstanta } \\
\mathrm{b}_{\mathrm{i}}= & \text { Koefisien regresi }(\mathrm{i}=1,2, \\
& \ldots .7) \\
\mathrm{X}_{1}= & \text { Luas lahan }(\mathrm{ha}) \\
\mathrm{X}_{2}= & \text { Tenaga Kerja }(\text { HKSP }) \\
\mathrm{X}_{3}= & \text { Benih }(\mathrm{kg})
\end{aligned}
$$

$$
\begin{aligned}
& X_{4}=\text { Pupuk Urea }(\mathrm{kg}) \\
& X_{5}=\text { Pupuk SP36 }(\mathrm{kg}) \\
& X_{6}=\text { Pupuk KCl }(\mathrm{kg}) \\
& X_{7}=\text { Pestisida }(\mathrm{kg})
\end{aligned}
$$

c. Efisiensi Faktor Produksi

Untuk mengetahui efisiensi faktor produksi padi digunakan pendekatan perbandingan Nilai Produk Marginal (NPM) dan Harga Faktor Produksi (HFP), dengan rumusan sebagai berikut:

$$
\begin{aligned}
& \mathrm{NPM}=\frac{\mathrm{b} \cdot \mathrm{Y} \cdot \mathrm{P}_{\mathrm{y}}}{\mathrm{X}} \\
& \frac{\mathrm{b} . \mathrm{Y} \cdot \mathrm{P}_{\mathrm{y}}}{\mathrm{X} \cdot \mathrm{P}_{\mathrm{x}}}=1
\end{aligned}
$$

dimana:

$$
\begin{aligned}
& \text { b }=\text { elastistisitas } \\
& \text { produksi (koefisien regresi) } \\
& \mathrm{Y}=\text { produksi } \\
& \text { Py = harga produksi } \\
& \mathrm{X}=\text { jumlah faktor } \\
& \text { produksi } \\
& \mathrm{P}_{\mathrm{x}}=\text { harga faktor }
\end{aligned}
$$

produksi X

$$
\begin{aligned}
\text { Jika } \frac{\text { b.Y.P. }}{X_{y}}>1 P_{x} & \text { dapat diartikan bahwa } \\
& \text { penggunaan } \quad \text { faktor } \\
& \text { produksi } X \text { tidak } \\
& \text { efisien dan perlu } \\
& \text { dikurangi } \\
& \text { penggunaannya. }
\end{aligned}
$$


Jika $\frac{\text { b.Y.P. }}{X_{y}}<1$ : dapat diartikan bahwa

$\begin{array}{lr}\begin{array}{l}\text { penggunaan faktor } \\ \text { produksi }\end{array} & \text { belum } \\ \text { efisien dan perlu } & \\ \text { ditambah } & \\ \text { penggunaannya } & \text { untuk } \\ \text { meningkatkan } & \\ \text { produksi } & \end{array}$

d. Tingkat Skala Usaha (Return to Scale)

HASIL DAN PEMBAHASAN

1. Kelayakan Usahatani Padi Sawah a. Biaya Produksi

Biaya usahatani di peroleh dari total biaya variabel ditambah biaya tetap. Dalam penelitian ini untuk tenaga kerja dalam keluarga dalam keluarga dan biaya sarana produksi yang dimiliki petani sendiri tidak diperhitungkan atau dengan kata lain biaya yang diperhitungkan adalah biaya yang dikeluarkan petani dalam bentuk rupiah secara nyata dalam kegiatan usahataninya.

Semua komponen biaya usahatani padi organik, kecuali penyusutan alat, adalah $15-48 \% \%$ lebih tinggi dibandingkan biaya usahatani padi konvensional. Komponen biaya terbesar untuk usahatani padi
Tingkat skala usaha (return to scale) adalah tingkat kenaikan produksi akibat penambahan penggunaan semua faktor produksi dalam suatu proses produksi. Untuk menguji hipotesis 4 bahwa tingkat skala usahatani padi sawah di Kecamatan Pandaan pada tahap tetap atau proporsional, digunakan pendekatan nilai RTS (return to scale), dengan menjumlahkan koefisien regresinya $\left(b_{i}\right)$ fungsi produksi Cobb-Douglas yang terbentuk.

konvensional maupun padi organik adalah biaya tenaga kerja. Biaya tenaga kerja dalam usahatani padi organik $15 \%$ lebih tinggi dibandingkan biaya tenaga kerja untuk usahatani konvensional. Total biaya yang digunakan dalam usahatani padi organik 22\% lebih besar dibandingkan biaya usahatani padi konvensional.

\section{b. Penerimaan dan RCR}

Perbedaan penggunaan biaya produksi menyebabkan perbedaan produksi padi yang dihasilkan. Produksi rata-rata yang diperoleh petani padi konvensional adalah $1.184 \mathrm{~kg} / \mathrm{ha}$, sedangkan padia organik adalah 1.855 $\mathrm{kg} / \mathrm{ha}$ (Tabel 4.7). Terlihat produksi usahatani padi organik 36\% lebih besar dari konvensional, hal ini menunjukkan dengan penggunaaan padi organik 
mampu meningkatkan produktivitas usahataninya. Berdasarkan harga jual padi konvensional sebesar Rp. 3.250/kg dan padi organik Rp. 3.000/kg, maka penerimaan usahatani padi organik adalah Rp. 5.565.663/ha atau 31\% lebih tinggi dibandingkan penerimaan usahatani padi konvensional sebesar Rp. 3.849.415/ha
Berdasarkan nilai RCR yang lebih besar dari 1 usahatani padi organik maupun konvensional semuanya menguntungkan dan layak dilaksanakan, usahatani padi organik lebih layak dan menguntungkan (RCR 2,72) dibandingkan dengan usahatani padi konvensional (RCR 2,42).

Tabel 1. Biaya, Penerimaan, Pendapatan dan RCR Usahatani Padi Konvensional dan Organik di Kecamatan Pandaan MT.2014/ 2015

\begin{tabular}{|c|c|c|c|c|c|c|}
\hline \multirow[t]{2}{*}{ No } & \multirow{2}{*}{$\begin{array}{l}\text { Komponen } \\
\text { Usahatani }\end{array}$} & \multicolumn{2}{|c|}{ Padi Konvensional } & \multicolumn{2}{|c|}{ Padi Organik } & \multirow[b]{2}{*}{$\begin{array}{c}\% \\
\text { beda }\end{array}$} \\
\hline & & $\begin{array}{c}\text { Per } \\
\text { usahatani }\end{array}$ & $\begin{array}{c}\text { Per } \\
\text { hektar }\end{array}$ & $\begin{array}{c}\text { Per } \\
\text { usahatani }\end{array}$ & $\begin{array}{c}\text { Per } \\
\text { hektar }\end{array}$ & \\
\hline 1 & Lahan (ha) & 1,21 & & 0,83 & & \\
\hline \multirow[t]{10}{*}{2} & $\begin{array}{l}\text { Biaya Variabel } \\
\text { (Rp) }\end{array}$ & & & & & \\
\hline & a. Sewa Lahan & 181.500 & 150.000 & 124.750 & 150.000 & $0 \%$ \\
\hline & b. Tenaga Kerja & 1.126 .280 & 930.810 & 909.333 & 1.095 .582 & $15 \%$ \\
\hline & c. Bibit & 19.320 & 15.967 & 18.013 & 21.702 & $26 \%$ \\
\hline & d. Urea & 224.425 & 185.475 & 232.650 & 280.301 & $34 \%$ \\
\hline & e. SP36 & 205250 & 169.628 & 227500 & 274.096 & $38 \%$ \\
\hline & f. $\mathrm{KCl}$ & 97.725 & 80.764 & 128.400 & 154.699 & $48 \%$ \\
\hline & g. Pestisida & 59.400 & 49.091 & 52.500 & 63.253 & $22 \%$ \\
\hline & h. Penyusutan Alat & 7.004 & 5.788 & 3.800 & 4.578 & $-26 \%$ \\
\hline & Total Biaya (Rp) & 1.920 .904 & 1.587 .524 & 1.696 .947 & 2.044 .514 & $22 \%$ \\
\hline \multirow[t]{3}{*}{3} & Produksi (kg) & 1.433 & 1.184 & 1.540 & 1.855 & $36 \%$ \\
\hline & Harga Jual (Rp/kg) & 3.250 & 3.250 & 3.000 & 3.000 & $-8 \%$ \\
\hline & Penerimaan (Rp) & 4.657 .792 & 3.849 .415 & 4.619 .500 & 5.565 .663 & $31 \%$ \\
\hline 4 & Keuntungan (Rp) & 2.736 .888 & 2.261 .891 & 2.922 .553 & 3.521 .148 & $36 \%$ \\
\hline 5 & $\mathrm{RCR}$ & 2,42 & & 2,72 & & \\
\hline
\end{tabular}




\section{c. Keuntungan}

Tujuan akhir dari usahatani padi konvensional dan organik adalah mendapatkan keuntungan (selisih total biaya dan penerimaan) dari kedua sistem budidaya padi keuntungan usahatani padi organik adalah Rp. $3.521 .148 /$ ha atau $36 \%$ lebih tinggi dibandingkan keuntungan usahatani konvensional sebesar Rp. 2.261.891/ha. Hasil analisis yang disajikan pada Lampiran 6 menunjukkan bahwa nilai thitung $=2,016$ lebih besar dari nilai $\mathrm{t}-$ tabel $=1,87$; maka keuntungan usahatani organik secara nyata lebih tinggi dibandingkan keuntungan usahatani konvensional pada taraf kepercayaan $95 \%$.

Ketimpangan imbangan perbedaan luas lahan usaha dengan perbedaan biaya, penerimaan, dan keuntungan tersebut di atas dapat disebabkan oleh 3 hal, yaitu (a) pengelolaan usahatani organik lebih intensif dibandingkan dengan pengelolaan usahatani padi konvensional, atau (b) terjadi pemborosan penggunaan biaya produksi, terutama biaya tenaga kerja dalam usahatani padi organik, atau (c) pengelolaan usahatani padi organik yang belum efisien.

\section{d.Pengaruh Faktor Produksi}

terhadap Produksi Padi Sawah

Produksi padi sawah dipengaruhi oleh faktor produksi yang digunakan dalam usaha. Faktor-faktor produksi tersebut adalah luas lahan, biaya saprotan dan biaya tenaga kerja. Sebenarnya terdapat faktor produksi lain yang sangat penting yaitu manajemen sebagai pengkoordinir semua faktor produksi yang lain sehingga benar-benar mengeluarkan hasil produksi (output). Dalam penelitian ini, aspek manajemennya tergambar pada nilai RCR. Dalam penelitian ini, hasil analisis penggunaan faktor produksi dilakukan dengan bantuan fungsi Cobb-Douglas, di mana variabel tidak bebas $\mathrm{Y}$ adalah produksi dan variabel bebas $\mathrm{X}$ adalah faktor produksi. Variabel $\mathrm{X}$ terdiri dari luas lahan $\left(\mathrm{X}_{1}\right)$, tenaga kerja $\left(\mathrm{X}_{2}\right)$, benih $\left(\mathrm{X}_{3}\right)$, pupuk urea $\left(\mathrm{X}_{4}\right)$, pupuk SP36 $\left(\mathrm{X}_{5}\right)$, pupuk $\mathrm{KCl}\left(\mathrm{X}_{6}\right)$, dan pestisida $\left(\mathrm{X}_{7}\right)$

\section{Organik}

Berdasarkan model fungsi produksi $\mathrm{Y}=\mathrm{f}\left(\mathrm{X}_{1}, \mathrm{X}_{2}, \mathrm{X}_{3}, \mathrm{X}_{4}, \mathrm{X}_{5}, \mathrm{X}_{6}\right.$, $X_{7}$ ), hasil analisis ragam (Lampiran 7 ), menunjukkan nilai $\mathrm{F}$ hitung sebesar 7,038 (Tabel 4.8 dan Lampiran 7). Nilai F tabel $(7,22)$ ada taraf kepercayaan 
95\% adalah 2,02, maka nilai $\mathrm{F}$ hitung > dari $\mathrm{F}$ tabel, dengan demikian hipotesis H1 diterima dan hipotesis Ho ditolak, artinya variasi produksi padi secara nyata dijelaskan oleh variasi faktor produksi.

Berdasarkan prakiraan koefisien regresi fungsi Cobb-Douglas maka dapat dijelaskan beberapa hal sebegai berikut:

1. Dijumpai elastisitas produksi yang negatif pada faktor benih $\mathrm{X}_{3}$ dan pupuk urea $\mathrm{X}_{6}$ tetapi elastisitasnya tidak nyata dilihat dari nilai t-hitung yang lebih kecil dibandingkan t-tabel. Angka negatif dapat disebabkan oleh kesalahan spesifikasi dari variabel yang digunakan.

2. Variabel luas lahan $\left(\mathrm{X}_{1}\right)$ berpengaruh nyata terhadap produksi padi, dimana t-hitung sebesar 2,051 lebih besar dari ttabel 1,87 pada taraf kepercayaan 95\%. Koefisien regresi sebesar 0,626 dapat diartikan bahwa untuk setiap penambahan luas lahan 1\% akan dapat meningkatkan produksi $0,628 \%$.Variabel pupuk urea $\left(\mathrm{X}_{4}\right)$ berpengaruh nyata terhadap produksi padi, dimana t-hitung sebesar 2,541 dan 2,151 lebih besar dari t-tabel 1,87 pada taraf kepercayaan 95\%. Koefisien regresi sebesar 0,803 dapat diartikan bahwa untuk setiap penambahan luas lahan 1\% akan dapat meningkatkan produksi $0,805 \%$ dan $0,448 \%$.

3. Variabel tenaga kerja $\left(\mathrm{X}_{2}\right)$, benih $\left(\mathrm{X}_{3}\right)$, pupuk SP36 $\left(\mathrm{X}_{5}\right)$, pupuk KCL $\left(\mathrm{X}_{6}\right)$ dan pestisida $\left(\mathrm{X}_{7}\right)$ tidak berpengaruh nyata terhadap produksi padi. Hal ini dapat dilihat pada t-hitung untuk masing-masing variabel tersebut lebih kecil dati t-tabel 1,87 pada taraf kepercayaan $95 \%$.

4. Nilai $\mathrm{R}^{2}=0,691$ dapat diartikan bahwa variasi produksi $\mathrm{Y}$ dapat diterangkan oleh variabel faktor produksi yang digunakan sebesar $69,1 \%$ sedangkan $30,9 \%$ tidak dapat diterangkan oleh variasi faktor produksi yang lain. Hal ini disebabkan oleh adanya pengaruh faktor produksi lain yang tidak dimasukkan dalam regresi, misalnya iklim, kesuburan tanah, pengelolaan dan lain-lain. 
Tabel 2. Prakiraan koefisien regresi (b) fungsi produksi Cobb-Douglas dalam Usahatani Padi Sawah Organik di Desa Prigen, Kecamatan Pandaan, Kabupaten Pasuruan tahun 2014/2015

\begin{tabular}{|c|c|c|c|}
\hline Variabel bebas & Uraian & Koefisien regresi & t-hitung \\
\hline $\ln 0$ & Konstanta & 4,213 & 2,594 \\
\hline $\ln X_{1}$ & Luas lahan & 0,626 & $2,051^{*}$ \\
\hline $\ln X_{2}$ & Tenaga Kerja & 0,361 & 1,784 \\
\hline $\ln X_{3}$ & Benih & $-0,349$ & $-1,007$ \\
\hline $\ln X_{4}$ & Pupuk Urea & 0,803 & $2,541^{*}$ \\
\hline $\ln X_{5}$ & Pupuk SP36 & 0,138 & 0,597 \\
\hline $\ln X_{6}$ & Pupuk KCl & $-0,448$ & $-1,467$ \\
\hline $\ln X_{7}$ & Pestisida & 0,035 & 0,249 \\
\hline & \multirow{4}{*}{$\begin{array}{l}\mathrm{R}^{2} \\
\text { F hitung } \\
\text { Taraf kepercayaan } 95 \%\end{array}$} & \multirow{4}{*}{$\begin{array}{c}0,691 \\
7,038 \\
\text { F tabel }=2,02 \\
\text { t-tabel }=1,87\end{array}$} & \\
\hline & & & \\
\hline & & & \\
\hline & & & \\
\hline
\end{tabular}

*) berbeda nyata pada taraf kepercayaan 95\%

\section{Konvensional}

Seperti halnya usahatani padi organik, model fungsi produksi yang digunakan adalah $\mathrm{Y}=\mathrm{f}\left(\mathrm{X}_{1}, \mathrm{X}_{2}, \mathrm{X}_{3}, \mathrm{X}_{4}\right.$, $\left.\mathrm{X}_{5}, \mathrm{X}_{6}, \mathrm{X}_{7}\right)$. Hasil analisis ragam menunjukkan bahwa nilai $F$ hitung sebesar 20,0498. Nilai F tabel $(7,22)$ ada taraf kepercayaan $95 \%$ adalah 2,02, maka nilai $\mathrm{F}$ hitung > dari $\mathrm{F}$ tabel, dengan demikian hipotesis $\mathrm{H} 1$ diterima dan hipotesis Ho ditolak, artinya variasi produksi padi secara nyata dijelaskan oleh variasi faktor produksi. Berdasarkan ketepatan model regresi faktor produksi luas lahan, tenaga kerja dan benih merupakan faktor produksi penting (dominan) yang mempengaruhi produksi padi konvensional.

Berdasarkan prakiraan koefisien regresi fungsi Cobb- Douglas maka dapat dijelaskan beberapa hal sebegai berikut:

1. Dijumpai elastisitas produksi yang negatif pada $X_{3}, X_{4}, X_{5}$, $\mathrm{X}_{6}$, dan $\mathrm{X}_{7}$ tetapi elastisitasnya tidak nyata dilihat dari nilai $\mathrm{t}$ yang kecil, kecuali untuk variabel benih. Angka negatif dapat disebabkan oleh kesalahan 
spesifikasi dari variabel yang digunakan.

2. Variabel luas lahan (X1) berpengaruh nyata terhadap produksi padi, dimana t-hitung sebesar 4,139 lebih besar dari ttabel 1,87 pada taraf kepercayaan 95\%. Koefisien regresi sebesar 2,804 dapat diartikan bahwa untuk setiap penambahan luas lahan $1 \%$ akan dapat meningkatkan produksi $2,804 \%$. Variabel tenaga kerja $\left(\mathrm{X}_{2}\right)$ berpengaruh nyata terhadap produksi padi, dimana t-hitung sebesar 3,339 lebih besar dari ttabel 1,87 pada taraf kepercayaan 95\%. Koefisien regresi sebesar 1,627 dapat diartikan bahwa untuk setiap penambahan tenaga kerja $1 \%$ akan dapat meningkatkan produksi $1,627 \%$, Variabel benih $\left(\mathrm{X}_{3}\right)$ berpengaruh nyata terhadap produksi padi, dimana t-hitung sebesar 2,725 lebih besar dari ttabel 1,87 pada taraf kepercayaan 95\%. Koefisien regresi sebesar 2,333 dapat diartikan bahwa untuk setiap penambahan benih $1 \%$ akan dapat menurunkan produksi $2,333 \%$,

3. Variabel pupuk urea $X_{4}$, pupuk SP36 $\mathrm{X}_{5}$, pupuk $\mathrm{KCl} \mathrm{X}_{6}$, dan pestisida $\mathrm{X}_{7}$ tidak berpengaruh nyata terhadap produksi padi. Hal ini dapat dilihat pada $\mathrm{t}$ hitung untuk masing-masing variabel tersebut lebih kecil dati t-tabel 1,87 pada taraf kepercayaan $95 \%$.

4. Nilai $R^{2}=0,818$ dapat diartikan bahwa variasi faktor produksi Y dapat diterangkan oleh variabel produksi yang digunakansebesar $81,8 \%$ sedangkan $19,2 \%$ tidak dapat diterangkan oleh variasi faktor produksi yang lain. Hal ini disebabkan oleh adanya pengaruh faktor produksi lain yang tidak dimasukkan dalam regresi, misalnya iklim, kesuburan tanah, pengelolaan dan lain-lain. 
Tabel 3. Prakiraan Koefisien Regresi (b) Fungsi Produksi Cobb-Douglas dalam Usahatani Padi Sawah Konvensional di Desa Prigen, Kecamatan Pandaan, Kabupaten Pasuruan tahun 2014/2015

\begin{tabular}{|c|l|c|c|}
\hline Variabel bebas & Uraian & Koefisien regresi & t-hitung \\
\hline $\ln 0$ & Konstanta & 7,233 & 1,952 \\
\cline { 3 - 4 } $\ln \mathrm{X}_{1}$ & Luas lahan & 2,804 & $4,139^{*}$ \\
$\ln \mathrm{X}_{2}$ & Tenaga Kerja & 1,627 & $3,339^{*}$ \\
$\ln \mathrm{X}_{3}$ & Benih & $-2,333$ & $-2,725^{*}$ \\
$\ln \mathrm{X}_{4}$ & Pupuk Urea & $-0,314$ & $-0,616$ \\
$\ln \mathrm{X}_{5}$ & Pupuk SP36 & $-0,009$ & $-0,023$ \\
$\ln \mathrm{X}_{6}$ & Pupuk KCl & $-0,115$ & $-0,195$ \\
$\ln \mathrm{X}_{7}$ & Pestisida & $-0,436$ & $-0,911$ \\
& R & 0,818 & \\
\cline { 3 - 4 } & F hitung & 20,498 & \\
\cline { 3 - 4 } & Taraf kepercayaan 95\% & F tabel = 2,02 & \\
\cline { 3 - 4 } & & $\mathrm{t}$-tabel = 1,87 & \\
\hline
\end{tabular}

*) berbeda nyata pada taraf kepercayaan $95 \%$

\section{e.Efisiensi Faktor Produksi dan}

\section{Return to Scale}

Dalam usahatani padi sawah organik dan konvensional, rata-rata penggunaan luas lahan adalah 0,83 dan 1,21 ha, tenaga kerja sebesar 90,93 HKSP dan 112,63 HKSP, benih 12,87 $\mathrm{kg}$ dan 13,80 kg, pupuk urea 99,0 kg dan 95,5 kg, pupuk SP36 60,67 kg dan $54,73 \mathrm{~kg}$, pupuk $\mathrm{KCl} 57,07 \mathrm{~kg}$ dan $43,43 \mathrm{~kg}$, pestisida $2,92 \mathrm{~kg}$ dan $3,30 \mathrm{~kg}$ untuk organik dan konvensional. Ratarata produksi padi organik adalah 1.540 $\mathrm{kg}$ dan konvensional $1.433 \mathrm{~kg}$.
Besarnya biaya yang digunakan dalam penelitian ini adalah rata-rata harga yang berlaku di Kecamatan Pandaan, yaitu sewa tanah Rp. 150.000/ha, benih padi Rp. $1.400 / \mathrm{kg}$, tenaga kerja Rp. 10.000/HKSP, pupuk urea Rp. 2.350/kg, pupuk SP36 Rp. 3.750/kg, pupuk $\mathrm{KCl}$ Rp.2.250/kg dan pestisida Rp. $18.000 / \mathrm{kg}$ Tabel 12 dan 13 . Berdasarkan Tabel 4.10 dan 4.11, maka rasio nilai produk marjinal dengan harga faktor produksi dapat dijelaskan sebagai berikut: 


\section{(a) Organik}

Nilai ratio NPM/HFP untuk semua variabel faktor produki usahatani padi sawah organik semuanya lebih besar dari satu; berarti penggunaan faktor produksi (luas lahan, tenaga kerja, benih, pupuk urea,pupuk SP36, pupuk $\mathrm{KCl}$ dan pestisida) masih sangat kurang sehingga perlu adanya usaha penambahan untuk mencapai tingkat yang efisien. Hasil penjumlahan nilai koefisien regresi diketahui bahwa nilai RTS (return to scale) adalah 1,166 lebih besar dari 1; berarti bahwa proses produksi berada pada tingkat skala usaha yang meningkat (increasing return to scale) artinya apabila semua faktor produksi ditambah secara proporsional sebesar satu unit, maka produksi akan meningkat lebih besar dari satu unit.

\section{(b) Konvensional}

Nilai rasio NPM/HFP untuk variabel luas lahan, tenaga kerja, benih, pupuk urea, pupuk $\mathrm{KCl}$ dan pestisida semuanya lebih besar dari satu; berarti penggunaan faktor produksi tersebut dalam usahatani padi sawah konvensional masih sangat kurang sehingga perlu ditambahkan untuk mencapai tingkat yang efisien. Variabel pupuk SP36 memiliki nilai rasio 0,169 yang lebih kecil dari satu; berarti penggunaan pupuk SP36 pada usahatani padi sawah konvensional sudah berlebihan, sehingga perlu adanya pengurangan untuk mencapai tingkat yang lebih efisien. Hasil penjumlahan nilai koefisien regresi diketahui bahwa nilai RTS (return to scale) adalah 1,224 lebih besar dari 1; berarti bahwa proses produksi berada pada tingkat skala usaha yang meningkat (increasing return to scale) artinya apabila semua faktor produksi ditambah secara proporsional sebesar satu unit, maka produksi akan meningkat lebih besar dari satu unit. 
Tabel 4. Prakiraan Besarnya Rasio Niai Produk Marginal (NPM) dengan Harga Faktor Produksi (HFP) pada Usahatani Padi Sawah Organik di Desa Prigen, Kecamatan Pandaan, Kabupaten Pasuruan Tahun 2014/2015

\begin{tabular}{|c|l|r|r|r|}
\hline No & Faktor Produksi & \multicolumn{1}{|c|}{ HFP } & \multicolumn{1}{c|}{ NPM } & \multicolumn{1}{c|}{ NPM/ HFP } \\
\hline 1 & Sewa Tanah (Rp/0,83 ha) & 124.500 & 3.483 .690 & 27,98 \\
2 & Tenaga Kerja (Rp/HKSP) & 10.000 & 22.093 & 2,21 \\
3 & Benih (Rp/kg) & 1.400 & -150.907 & 107,79 \\
4 & Pupuk Urea (Rp/kg) & 2.350 & 45.138 & 19,21 \\
5 & Pupuk SP36 (Rp/kg) & 3.750 & 12.658 & 3,38 \\
6 & Pupuk KCl (Rp/kg) & 2.250 & -43.685 & 19,42 \\
7 & Pestisida (Rp/kg) & 18.000 & 66.703 & 3,71 \\
\hline
\end{tabular}

Keterangan: Harga Jual Padi Organik Rp. 3000/kg; Rata-rata produksi 1855 kg/ha

Tabel 5. Prakiraan besarnya Rasio Niai Produk Marginal (NPM) dengan Harga Faktor Produksi (HFP) pada Usahatani Padi Sawah Konvensional di Desa Prigen, Kecamatan Pandaan, Kabupaten Pasuruan. Tahun 2014/2015

\begin{tabular}{|c|l|r|r|r|}
\hline No & Faktor Produksi & \multicolumn{1}{c|}{ HFP } & \multicolumn{1}{c|}{ NPM } & \multicolumn{1}{c|}{ NPM/ HFP } \\
\hline 1 & Sewa Tanah (Rp/1,21 ha) & 181.500 & 10.789 .792 & 59,448 \\
2 & Tenaga Kerja (Rp/HKSP) & 10.000 & 55.586 & 5,559 \\
3 & Benih (Rp/kg) & 1.400 & -650.535 & 464,67 \\
4 & Pupuk Urea (Rp/kg) & 2.350 & -12.652 & 5,384 \\
5 & Pupuk SP36 (Rp/kg) & 3.750 & -632 & 0,169 \\
6 & Pupuk KCl (Rp/kg) & 2.250 & -10.189 & 4,529 \\
7 & Pestisida (Rp/kg) & 18.000 & -508.402 & 28,245 \\
\hline
\end{tabular}

Keterangan: Harga Jual Padi Konvensional Rp. 3250/kg; Rata-rata produksi 1184 kg/ha Berdasarkan uraian yang ditinjau nilai RCR 2,42 (konvensional) disajikan di atas, secara umum dapat dinyatakan bahwa usahatani padi sawah dengan menggunakan organik maupun konvensional layak untuk dilaksanakan dan 2,72 (organik) dengan keuntungan yang berbeda nyata. Semua faktor produksi berpengaruh nyata terhadap produksi padi organik maupun 
konvensional. Namun demikian, faktor produksi usahatani padi sawah organik hanya dapat menjelaskan $69,1 \%$ variasi produksi padi organik, sementara faktor produksi usahatani padi konvensional dapat menjelaskan $81,8 \%$ variasi produksi konvensional. Nampaknya usahatani padi organik perlu melibatkan lebih banyak faktor produksi dibandingkan konvensional, hal ini mungkin terkait dengan karakteristik organik yang sangat berbeda dengan konvensional, terutama dalam kemampuan berproduksi. Merujuk pada nilai RTS, baik usahatani padi organik maupun konvensional pada skala meningkat, yang berarti produksi masih dapat di tingkatkan dengan perbaikan tingkat efisiensi faktor produksi. Pada usahatani padi organik, semua faktor produksi yang digunakan masih kurang efisien, sehingga diperlukan penambahan agar tercapai produksi yang tinggi. Pada usahatani padi konvensional hanya variabel pupuk SP36 yang perlu dikurangi penggunaannya karena sudah berlebihan, sedangkan faktor produksi lainnnya masih perlu di tingkatkan penggunaannnya. Peningkatan efisiensi penggunaan lahan dapat dilakukan dengan penggabungan areal lahan usaha.

\section{KESIMPULAN}

1. Kelayakan Usahatani

a. Usahatani padi organik menguntungkan dan layak untuk dilakukan ditinjau dari nilai RCR organik 2,72 dan nilai RCR konvensional 2,42.

b. Keuntungan usahatani padi sawah organik adalah Rp $3.521 .148 /$ ha atau $36 \%$ lebih tinggi dibandingkan konvensional sebesar Rp. 2.261.891/ha. Berdasarkan uji $t$, perbedaan keuntungan tersebut nyata pada taraf kepercayaan $95 \%$.

2. Pengaruh Faktor Produksi

a. Faktor produksi lahan, tenaga kerja, benih, pupuk urea, pupuk $\mathrm{KCl}$, pupuk SP36 dan pestisida secara simultan berpengaruh nyata terhadap produksi padi organik maupun konvensional. Untuk organik, variasi faktor produksi memberikan kontribusi $\quad 69,1 \%$ terhadap variasi produksi padi organik, sedangkan untuk konvensional, variasi faktor produksi 
memberikan kontribusi 81,8\% terhadap variasi produksi padi konvensional.

b. Faktor produksi yang dominan mempengaruhi produksi padi sawah organik adalah luas lahan dan pupuk urea, sedangkan pada padi sawah konvensional adalah luas lahan, tenaga kerja dan benih.

3. Efisiensi Faktor Produksi

a. Faktor produksi lahan, tenaga kerja, benih, pupuk urea, pupuk $\mathrm{KCl}$, pupuk SP36 dan pestisida masih sangat kurang untuk produksi padi organik, sehingga perlu ditambahkan untuk mencapai tingkat yang efisien.

b. Faktor produksi lahan, tenaga kerja, benih, pupuk urea, pupuk $\mathrm{KCl}$, dan pestisida masih sangat kurang untuk produksi padi konvensional sehingga perlu ditambahkan untuk mencapai tingkat yang efisien. Faktor produksi pupuk SP36 sudah berlebihan sehingga perlu dikurangi untuk mencapai tingkat yang efisien.

4. Tingkat skala usahatani
Proses produksi padi organik maupun konvensional berada pada tingkat skala usaha yang meningkat (increasing return to scale) yang berarti apabila semua faktor produksi ditambah sebesar satu unit, maka produksi akan meningkat lebih besar dari satu unit.

\section{DAFTAR PUSTAKA}

Adiwilaga, A. 1974. Ilmu Usahatani. Alumni, Bandung.

Anonymous 1983. Pedoman Bercocok Tanam Padi, Palawija dan Sayur-Sayuran. Departemen Pertanian Satuan Pengendalian Bimas. Jakarta.

Anonymous 1997. Dampak Supra Insus Padi Sawah Terhadap Produktivitas Usahatani dan Pendapatan Petani Peserta Kecamatan Dusun Tengah Kabupaten Barito Selatan (Makalah) Fakultas Pertanian Universitas Palangka Raya.

Badan Pusat Statistik Kabupaten Barito Timur. 2005. Barito Timur dalam Angka tahun 2004. Penduduk Kabupaten Barito Timur tahun 2004. Kerjasama Badan Perencanaan Pembangunan Daerah Kabupaten Barito Timur dengan Badan Pusat Statistik Kabupaten Barito Timur.

Bari, Abdul., Musa, Sjarkani, dan Samsudin. 1974. Pengantar 
Pemuliaan Tanaman, Dept Agronomi Fakultas Pertanian IPB Bogor.

Boediono. 1984. Pengantar Ilmu Ekonomi. Fakultas Ekonomi. Universitas Gajah Mada. Yogyakarta.

Dinas Pertanian dan Ketahanan Pangan Kabupaten Barito Timur .2005. Laporan survei potensi di Kabupaten Barito Timur tahun 2005. Kerjasama Badan Perencanaan Pembangunan Daerah Kabupaten Barito Timur dengan Dinas Pertanian dan Ketahanan Pangan Kabupaten Barito Timur tahun 2005.

Doll, J. P. and F. Orazem, 1984. Production Economic, Theory with Aplication $2^{\text {nd }}$ Edition, jhon Willey and Sons Inc, New York.

Gujarati, D., 1995. Ekonometrika Dasar, Terjemahan, Penerbit Erlangga, Jakarta

Hernanto, 1989. Ilmu Usahatani. Penebar Swadaya, Jakarta.

$\begin{array}{clrr}\text { Jumin } & \text { H.B } 1987 & \text { Dasar- } & \text { Dasar } \\ & \text { Agronomi } & \text { Rajawali } & \text { Press } \\ \text { Jakarta. } & & \end{array}$

Kartasapoetra, A.G. 1987. Ilmu Usahatani. Penebar Swadaya. Jakarta.

Kasim, S., 1995. Pengantar Ekonomi Produksi Pertanian, Lambung Mangkurat University Press, Banjarmasin.
Mubyarto 1989. Pengantar Ekonomi Pertanian. LP3ES, Jakarta. 305 p.

Nicholson, W. 1978. Microeconomics Theory, $2^{\text {nd }}$ Edition, The Dryden Press, Illinois.

Pappas, J.L. and Hirschey., M. 1995. Ekonomi Manareial, Terjemahan, Binarupa Aksara, Jakarta.

Singarimbun, Masri 1989. Metode Penelitian Survei. LP3ES. Jakarta. 336 Halaman.

Soeharjo, A., dan Patong, D. 1973.

Sendi-Sendi Pokok Ilmu

Usahatani.Departemen Ilmu-Ilmu Sosial

Ekonomi Fakultas Pertanian IPB.Bogor.

Soekartawi, Suhardjo, A., Dillon, J.L. dan Hardaker, J.B. 1986. Ilmu Usahatani dan Penelitian Untuk Pengembangan Petani kecil, Universitas Indonesia. Jakarta

Soekartawi. 1995. Analisis Usaha Tani. Penerbit Universitas Indonesia, Jakarta

Soekartawi. 1997. Agribisnis: Teori dan Aplikasinya.Penebit PT RajaGrafindo Persada.Jakarta.

Soemartono, B. 1983. Bercocok Tanam Padi. Fakultas Pertanian Universitas Palangka Raya. Palangka Raya.

Soetrisno, P.H. 1988. Analisa Usahatani. Direktorat Jendral 
Ekonomi. Universitas Gajah Mada. Yogyakarta.

Widodo, Sri. 1993. Ilmu Ekonomi

Pertanian dan Pembangunan,

Agro Ekonomi Vol. IV no. 1

Desember 1994. 